\title{
Renovating Canada's Constitutional Architecture: An Examination of the Government's Democratic Reform Initiatives
}

\author{
Josh Hunter
}

The current federal government was elected on a platform promising significant changes to Canada's democratic institutions. Among several other reform proposals, the Liberals promised that "2015 will be the last federal election conducted under the first-past-the-post voting

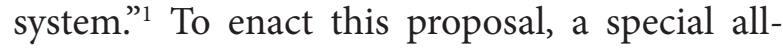
party parliamentary committee would be struck to examine options for reform and "within 18 months of forming government," the Liberals would "bring forward legislation to enact electoral reform." ${ }^{2}$ After the Liberals won the election, Maryam Monsef was appointed as Minister of Democratic Institutions. Her mandate letter from the Prime Minister confirmed the government's plans to move forward with electoral reform. Ms. Monsef was directed to:

\section{Bring forward a proposal to establish a special parliamentary committee to consult on electoral reform, including preferential ballots, proportional representation, mandatory voting and online voting. ${ }^{3}$}

As promised, on May 10, 2016, Minister Monsef gave notice of a motion to establish a Special Committee on electoral reform "to identify and conduct a study of viable alternative voting systems." 4 The committee was to be composed of ten voting members (6 Liberals, 3 Conservatives, and 1 NDP) with an additional member from the BQ and the Green party who could not vote or move motions. ${ }^{5}$ In response to opposition concerns about the Liberals having a majority on the committee, the government agreed to instead support a motion moved by NDP MP Nathan Cullen (as modified by a friendly amendment from Minister Monsef) that changed the composition of the committee to twelve voting members ( 5 Liberals, 3 Conservatives, $2 \mathrm{NDP}, 1 \mathrm{BQ}$, and 1 Green). ${ }^{6}$ The Committee met on June 21 , 2016 to elect a Chair and Vice-Chair and on June 29, 2016 to plan how to conduct its work. ${ }^{7}$ Every MP was invited to hold a town hall over the summer to gather the views of their constituents and report back to the Committee. The Committee has been meeting regularly over the last few months to hear witnesses and receive the reports of MPs' consultation. It is required to present its final report to the House by December 1, 2016

To illustrate the types of electoral reform the committee may wish to recommend, this paper will examine the various electoral systems that have been adopted or proposed in comparable Commonwealth jurisdictions and at the provincial level in Canada. It will then discuss whether a constitutional amendment or ordinary statutory change would be needed to implement those various systems in Canada.

The government has faced strong pressure from the Official Opposition to hold a referendum before it makes any changes to the existing 
referendum. So far, it has resisted those calls, except to give the Special Committee on Electoral Reform the power to "study and advise on additional methods for obtaining the views of Canadians," which could arguably include a referendum. ${ }^{8}$ This paper will examine the electoral reform referenda that have been held in other Commonwealth countries and in several Canadian provinces. It will also consider whether a constitutional convention has arisen requiring any major changes to Canada's electoral system to be approved by referendum.

\section{Reform Examples from Other Commonwealth Democracies}

Under the first-past-the-post system, whichever candidate wins a plurality of the votes cast in an electoral district or riding is elected as the representative of that riding. Although most modern Western democracies use a voting system other than the first-past-the-post system, the most illustrative examples for the purposes of this discussion come from countries whose Parliaments are otherwise similar to Canada's: New Zealand, Australia, and the United Kingdom. Between them, they provide examples of the three main alternatives to the first-past-the-post system: tie Alternative Voting (AV); Single Transferable Vote (STV); and Mixed Member Proportional (MMP) systems.

As in first-past-the-post, AV uses one representative per riding but allows voters to rank more than one candidate as their first, second, etc. choice. If the candidate with the most votes does not obtain a majority of the votes, the candidate with the fewest votes is eliminated, and their voters' second-choice preferences are allocated to other candidates. This process is repeated until one candidate obtains a majority of the votes and is elected. As discussed in greater detail below in relation to the Australian Senate, STV uses multi-member constituencies where voters rank their preferences for party lists or individual candidates and a mathematical formula is used to determine which representatives are elected (the formula ensures representatives are chosen in approximate proportion with each party's share of the vote). MMP systems uses a mix of single-member constituencies elected under the first-past-the-post system and additional list members appointed to equalize the number of representatives each party has with the party's share of the vote.

\section{New Zealand}

The New Zealand Parliament has always been able to set the rules for elections by ordinary legislation. ${ }^{9}$ Until 1996, House of Representatives elections were usually conducted using the first-past-the-post system. ${ }^{10}$ In 1914, Parliament passed a law to change the Legislative Council from an appointed body to one elected by STV. ${ }^{11}$ The change was never implemented before the Legislative Council was abolished in $1950{ }^{12}$ Since 1996, however, members of the now-unicameral House of Representatives have been elected using MMP. ${ }^{13}$

In the 1978 and 1981 elections, Labour secured more votes overall than the governing National Party but National won more seats and remained the government. After Labour won the 1984 election, it established a Royal Commission on the Electoral System in early 1985, which recommended adopting MMP. Although neither Labour nor National liked MMP, both parties attempted to outmanoeuvre each other by promising to hold referenda on electoral reforms if they were successful in the 1990 election. ${ }^{14}$

National won and, under increasing political pressure to respond to public demands for electoral reform, agreed to hold a non-binding referendum on 19 September 1992. Voters were asked whether they wanted to change the existing voting system and whether they preferred MMP, STV, a supplementary member system (a system similar to MMP but where only the list seats are allocated proportionately to the parties' shares of the vote without regard to who one the first-past-the-post seats), or $\mathrm{AV} .^{15}$ If there was majority support for change, the government promised it would hold a binding referendum to choose between first-past-the-post and the most popular alternative. Although turnout was only $55 \%, 85 \%$ of those voting supported changing the electoral system while $70 \%$ favoured MMP. 
The second binding referendum was held at the same time as the 1993 election resulting in a much higher $85 \%$ turnout. MMP was chosen by $54 \%$ of those voting and was implemented for the 1996 and subsequent elections. ${ }^{16}$

In the New Zealand MMP system, each elector can vote for both an electorate MP and a party. ${ }^{17}$ Half of the 120 MPs are electorate MPs elected in single-member constituencies under a first-past-the-post system. ${ }^{18}$ The other half are selected from ranked lists established by the parties ("party lists") ${ }^{19}$ in the proportions needed to ensure each party's share of the total number of MPs corresponds to its share of the party vote. Parties must either obtain 5\% of the party vote or win at least one electorate seat to obtain any party list MPs. If a party has more electorate MPs than its share of the party vote would entitle it to, it keeps those MPs but the size of Parliament is increased by that number of seats until the next general election (an "overhang"). ${ }^{20}$

In 2009, the National government announced plans to hold another referendum on the future of MMP at the same time as the 2011 election. Over $56 \%$ of those voting supported retaining MMP. A second question asked what voting system should be adopted if there were to be a change. Returning to first-past-the-post was the most popular alternative, receiving almost $47 \%$ of the vote. ${ }^{21}$ Keeping the MMP system triggered an automatic review of the system by the Electoral Commission. ${ }^{22}$ On 29 October 2012, the Commission presented its final report to the Minister of Justice. The Commission recommended reducing the threshold for obtaining party list MPs to $4 \%$ of the party vote, abolishing the threshold of one electorate seat for obtaining party list MPs and the provision for overhang seats, and considering changing the ratio of electorate seats to party list seats from 50:50 to 60:40. ${ }^{23}$ To date, Parliament has not enacted any of the changes the Commission recommended.

Finally, since 1867, New Zealand has had dedicated seats for Māoris. Originally, there were four Māori seats and Māori voters could only vote for Māori seats. ${ }^{24}$ Since 1975, electors of Māori descent have been able to choose during each census whether to enroll in general or Māori seats. When MMP was adopted, the number of Māori electorates was allowed to vary according to the size of the Māori electoral population. ${ }^{25}$ Currently, there are seven Māori seats in addition to the 120 general seats. ${ }^{26}$

\section{Australia}

\section{Commonwealth elections}

Since Australia's creation, the Commonwealth Senate and House of Representatives have both been elected houses chosen directly by the people. ${ }^{27}$ State election laws governed the first Commonwealth election but ceased to apply when Parliament provided otherwise in 1902. ${ }^{28}$ The Commonwealth Parliament has the power to make laws prescribing the method of selecting Senators, but such laws must be uniform for all the States; subject to that power, State Parliaments may also make laws prescribing the method of selecting Senators. ${ }^{29}$ The Commonwealth Parliament has the power to make laws concerning the method of selection of MPs. ${ }^{30}$

Initially, Commonwealth elections were conducted on a first-past-the-post basis (electors had to vote for the total number of Senators to be elected for their state for their Senate ballot to be counted). ${ }^{31}$ In 1918, however, the first-pastthe-post system for MPs was replaced by AV in response to the rise of the Country Party after the First World War and the prospect of it splitting the non-Labor vote. ${ }^{32}$ Voters must rank all candidates for their ballot to count. ${ }^{33}$ If no candidate receives an absolute majority of first preference votes, the candidate who receives the fewest first preference votes is excluded and each of his or her ballot-papers is counted for the candidate next in the order of the voter's preferences. The process of eliminating the candidate with the fewest votes and reallocating his or her votes to the next candidate in order of preference is repeated as needed until a candidate obtains an absolute majority of votes. ${ }^{34} \mathrm{~A}$ similar system was put in place for Senate elections in time for the 1919 general election (although voters did not have to rank all candidates until 1934). ${ }^{35}$ In 1924, voting in House of Representative and Senate elections was made mandatory. ${ }^{36}$ 
In 1948, further reforms were made to the method of voting for Senators. AV was replaced by STV. Until 2016, voters had to indicate a ranked preference next to each candidate "below the line" for their ballot to count or choose to rank all candidates in the order preferred by their political party of choice by marking that party as their choice "above the line." ${ }^{37}$ A candidate had to achieve a quota of votes (determined by taking the total number of unspoiled ballot papers divided by the number of Senators to be elected plus one and then adding one to the result) to be elected. Any candidate who achieved the quota or more of first preference votes is elected. If any candidate achieved more votes than the quota, the second preference of all the ballots that ranked that candidate first are counted but at a discounted rate (determined by the candidate's surplus number of votes divided by the candidate's total number of votes). If all surplus votes from elected candidates are transferred and vacancies still remain, the unelected candidate with the lowest number of votes is excluded and his or her votes are redistributed to the candidate next in order of preference. If any of the remaining candidates obtain a quota through this process of distribution, they are elected and any surplus they have is distributed to other candidates before the next lowest-ranking candidate is excluded. The process is repeated until all vacancies are filled (the last vacancy can be filled by a majority of votes even if it is less than the quota). Due to the complexity of the system, it can take several weeks before the results of a Senatorial election is known. ${ }^{38}$

In recent years, the ability of voters to vote "above the line" has been manipulated by personality-based or single-issue micro-parties that agree to allocate their preferences to each other. For example, four independents and four singleSenator micro-parties (including the Australian Motoring Enthusiast Party) currently hold the balance of power in the Senate. ${ }^{39}$ To combat this problem, the government introduced changes to the Senate election rules. Although opposition from Labor and all but one of the independent or micro-party Senators delayed passage of the Bill (there was over 40 hours of debate in the Senate on the bill, including 28 hours straight at
Third Reading), it eventually passed 36-23 with the support of the Greens and independent Senator Nick Xenophon. The next day, it passed the House of Representatives 81-31. ${ }^{40}$

Under the new rules, voters no longer need to number every candidate below the line for their ballot to be counted. Instead, voters will have to either number at least six boxes above the line for their preferred parties or groups or at least twelve boxes below for individual candidates in their order of choice. Parties and groups will no longer be able to register group voting tickets to direct voter preferences - voters now have to do so themselves. ${ }^{41}$ On 13 May 2016, the High Court ruled that the new Senate ballot paper complied with the provisions of the Constitution governing Senate elections. ${ }^{42}$ The changes come into force on 1 July 2016 and thus will apply to the Senate election being held on 2 July $2016 .{ }^{43}$

\section{State elections}

Most of the State Legislative Assemblies are elected using the same AV system as the Commonwealth House of Representatives, except that in New South Wales (NSW) and Queensland, voters do not have to rank every candidate for their ballot to be counted. ${ }^{44}$ Tasmania and the Australian Capital Territory (ACT) use a form of STV that is similar to that used for federal Senate elections. However, voters need only rank as many candidates as there are vacancies to be filled. ${ }^{45}$

The States' Legislative Councils are elected by a variety of proportional representation systems. In NSW, Victoria, South Australia, and Western Australia, an STV system similar to that used for the Commonwealth Senate is used (except that voters only have to rank at least fifteen candidates in NSW or five candidates in Victoria). ${ }^{46}$ Tasmania uses an optional preferential voting system that is the same as that used in the Commonwealth House of Representatives except that voters do not have to rank every candidate. ${ }^{47}$ Queensland abolished its Legislative Council in 1922 while the ACT and Northern Territory have never had Legislative Councils. ${ }^{48}$ 
In NSW and the ACT, changes to the electoral system must be approved by the majority of voters voting in a referendum (and in ACT by $2 / 3$ of the members of the Legislative Assembly). ${ }^{49}$ Otherwise, the electoral rules in Australia can be changed by ordinary Commonwealth or State legislation without any need to hold a referendum.

\section{The United Kingdom}

Elections to the House of Commons continue to be conducted under the traditional first-pastthe-post system. ${ }^{50}$ There were several attempts to introduce a different voting system in the $20^{\text {th }}$ century but none of them succeeded. In 1910, a Royal Commission was appointed to enquire into electoral systems that might provide a more representative character to the House of Commons. It considered STV the most appropriate form of proportional representation for English conditions but in the end found that the benefits of proportional representation did not outweigh the downsides. It instead recommended the adoption of AV (essentially the Australian system)..$^{51}$

When the Representation of the People Bill was introduced in 1917, it originally provided for a mix of AV and STV. ${ }^{52}$ The provision for STV was deleted (except for university constituencies) by the House of Commons in committee but the provision for AV passed. ${ }^{53}$ The Lords, however, preferred STV to $A V .^{54}$ In response, the Commons insisted on AV. ${ }^{55}$ Eventually, a compromise was reached whereby the Boundary Commissioners would prepare a scheme to introduce STV for 100 seats to be approved by Parliament. ${ }^{56}$ The scheme was duly prepared but was rejected by the House of Commons in May $1918 .{ }^{57}$

Private members' bills to introduce STV or alternative voting were rejected in 1921, 1923, and $1924 .{ }^{58}$ Finally, in 1931, the minority Labour government was able to get a bill providing for AV through the House of Commons. A proposed amendment in the Lords to provide for STV instead was withdrawn as outside the scope of the Bill but an amendment to limit AV to boroughs with populations more than 200,000 passed. The
Bill died when the Lords' amendments were not passed by the Commons before the Labour government resigned and was replaced by a coalition National Ministry. ${ }^{59}$

In May 2011, a UK-wide referendum was held on whether first-past-the-post should be replaced with $\mathrm{AV} .^{60}$ The proposed system was an optional preferential ballot similar to that used in Legislative Assembly elections in NSW and Queensland. Voters could rank as many candidates as they wished. If no candidate achieved a majority of first-preference votes, the candidate with the lowest number of votes would be eliminated and his or her second-preference votes would be allocated to other candidates. If no candidate had a majority, the process would continue until one did. ${ }^{61}$ Only $42.2 \%$ of registered electors turned out to vote but, of those voting, $67.9 \%$ supported retaining the existing first-pastthe-post system. ${ }^{6}$

Although the House of Commons continues to use first-past-the-post, AV is now used to select one portion of Parliament. After all but 92 hereditary peers were excluded from the House of Lords in 1999, the Lords decided to use AV to conduct the by-elections required when the remaining hereditary peers died or resigned their seats. ${ }^{63}$

When devolved assemblies were created in Scotland, Wales, and Northern Ireland, Parliament decided that proportional voting systems should be used to elect the devolved assemblies' members. The Northern Ireland Assembly uses an STV system in which each constituency elects six members. Electors can rank as many or as few candidates as they wish. ${ }^{64}$ The Scottish Parliament and the National Assembly for Wales use an Additional Member System ("AMS") that is similar to New Zealand's MMP system in which voters vote for both an individual candidate and a party. Individual candidates are elected to single-member constituencies using first-past-thepost while additional members in a larger region are chosen from party lists to ensure each party's total share of Parliament or the Assembly's seats is proportionate to its overall share of the vote. ${ }^{65}$ In each of the devolved jurisdictions, devolution was approved by a referendum. The pro- 
posed proportional representation voting system for each devolved assembly was included in the government proposals leading up to each referendum but the electorate was not given a choice as to which voting system should be adopted they had to vote for or against devolution as a whole. $^{66}$

\section{Previous Attempts at Electoral Reform in Canada}

\section{British Columbia}

British Columbia has attempted electoral reform on two occasions in recent years. After the 2001 provincial election, the Legislative Assembly created a Citizens' Assembly on Electoral Reform to consult with British Columbians and consider whether a different model for electing members of the Legislative Assembly should be adopted. ${ }^{67}$

After a lengthy consultation, public hearing, and deliberation process, the Assembly voted 123-31 that STV would serve British Columbia better than MMV. It then voted 142-11 to recommend not retaining first-past-the-post and 146-7 to recommend STV to the people of British Columbia to consider in a referendum. ${ }^{68}$ Under the Citizens' Assembly's proposed STV system, each electoral district would elect between 2 and 7 members depending on their population. Voters would be free to rank as many or as few candidates as they wished but there would be no "above-the-line" option to rank candidates as a political party suggested. Ballots would be counted in a similar fashion to the STV models used in Tasmania and the ACT. ${ }^{69}$

The question "Should British Columbia change to the BC-STV electoral system as recommended by the Citizens' Assembly on Electoral Reform" was put to British Columbians in a referendum held at the same time as the 2005 general election. ${ }^{70}$ To be binding on the government, at least $60 \%$ of valid votes cast had to vote "yes" and at least $50 \%$ of the valid votes cast in at least $60 \%$ of BC's electoral districts had to vote "yes." The second threshold was passed (more than $50 \%$ voted "yes" in 77 out of 79 electoral districts) but the first was not (only 57.69\% overall voted "yes."). ${ }^{71}$

Given the close result, the government decided to hold a second referendum (originally scheduled to be held at the same time as the 2008 municipal election but later rescheduled to the 2009 provincial general election). Rather than have a "yes or no" question, the second referendum asked British Columbians "Which electoral system should British Columbia use to elect members to the provincial Legislative Assembly? The existing electoral system (first-past-the-post) / The single transferable vote system (BC-STV) proposed by the Citizens' Assembly on Electoral Reform?"72 This time, neither threshold was reached - only $39.09 \%$ overall voted for the BCSTV system and in only 8 out of the 85 electoral districts did more than $50 \%$ vote for BC-STV. ${ }^{73}$

\section{New Brunswick}

In 2003, the New Brunswick government established a Commission on Legislative Democracy to study democratic reform in New Brunswick. Among other recommendations, the Commission recommended implementing proportional representation for elections to the New Brunswick Legislative Assembly. It recommended the adoption of MMP with 36 single-member riding seats and 20 party list seats elected within four approximately equally-sized regions. ${ }^{74}$ It also recommended that the government hold a binding referendum on whether to adopt the new system. ${ }^{75}$ The government initially adopted the Commission's recommendations and agreed to hold a referendum at the same time as the 2008 municipal elections. ${ }^{76}$ Before that referendum was held, however, the government was defeated and the new government decided to retain firstpast-the-post without holding a referendum. ${ }^{77}$

\section{Prince Edward Island}

In 2003, retired Prince Edward Island Chief Justice Carruthers was appointed as a commission of inquiry to investigate the appropriateness of changing PEI's electoral system. He recommended the adoption of an MMP system similar to that of New Zealand with about 21 riding seats and 10 party list seats. ${ }^{78}$ In response, the Legis- 
lative Assembly passed a motion directing the appointment of an eight-member Commission on Prince Edward Island's Electoral Future to develop a public education program, to develop a plebiscite question, and to recommend when a plebiscite should be held. ${ }^{79}$ The Commission altered Justice Carruthers's seat breakdown to 17 riding seats and 10 party list seats. ${ }^{80}$

As recommended by the Commission, the question "Should Prince Edward Island change to the Mixed Member Proportional System as presented by the Commission on PEI's Electoral Future?" was put to the voters in a plebiscite on November 28, 2005. ${ }^{81}$ The Premier announced that the government would implement MMP if the change was approved by $60 \%$ of voters and the majority of voters in $60 \%$ of electoral ridings. In the end, only $33 \%$ of the electorate turned out in the plebiscite and $64 \%$ voted "no." 82

In July 2015, the newly elected Liberal government released a White Paper on Democratic Renewal proposing the adoption of AV with four large districts aligned with the federal ridings and six small single-member ridings within each large district, for a total of 28 MLAs. ${ }^{83}$ The Legislative Assembly responded by striking a Special Committee on Democratic Renewal. After conducting public hearings, it issued its First Report recommending that a plebiscite on electoral reform take place in November 2016, that community consultations concerning the plebiscite question take place in early 2016, and that the new systems to be presented to the public for discussion include the current first-pastthe-post with the addition of seats for leaders of political parties that receive a certain threshold in the popular vote; a preferential vote system; MMP; dual-member MMP; and the maintenance of the current system. ${ }^{84}$ The Committee's report was accepted unanimously by the Legislative Assembly. ${ }^{85}$

In April 2016, the Committee issued its Second Report recommending that the plebiscite use a ranked multi-option ballot listing the current first-past-the-post system and the four reform options the Committee identified. ${ }^{86}$ Again, the Committee's report was accepted unanimously by the Legislative Assembly. ${ }^{87}$ The Plebiscite Act was also amended to allow the Lieutenant Governor in Council to make orders for the conduct of the plebiscite, including permitting the use of telephone and online voting and allowing 16 and 17 -year olds to vote. ${ }^{88}$ Voting in the plebiscite took place online and by telephone from October 29 to November 7, 2016, and in person on November 4 and 5, 2016. At the time of writing, the results were not yet available.

\section{Nova Scotia}

After voter turnout in the July 2015 by-elections dipped below $38 \%$ in one riding, Nova Scotia's Premier floated the idea of considering a preferential vote system with reporters. He did not, however, commit to bringing forward electoral reform in this mandate and stated he would consult with opposition parties before taking any action. ${ }^{89}$ To date, the government has not taken any further action.

\section{Manitoba}

Manitoba's Premier announced in December 2015 that an all-party task force would examine possible electoral changes, including whether the current first-past-the-post system should be replaced. The task force was only intended to start once the federal government has concluded its electoral system review. ${ }^{90}$ After defeating the NDP government in the April 2016 provincial election, however, the new Conservative government has not indicated any intention to consider electoral reform.

\section{Québec}

In February 2003, the Estates General on the Reform of Democratic Institutions was held in Québec City. Over 1000 citizens participated in a series of workshops on democratic reforms. Those workshops had been preceded by town hall meetings across Québec at which the Estates General's Organizing Committee had met with more than 2,050 people. In March 2003, the Organizing Committee submitted its report to the Minister responsible for the Reform of Democratic Institutions. It recommended that the existing first-past-the-post system be replaced by a system called panachage. The National 
Assembly would be made up of 125 ridings. Each region of Québec would elect the same number of MNAs as it previously did but on a regionwide basis whereby voters would have as many votes as the total number of MNAs to be elected for the region. ${ }^{91}$

Two days after the report was released, a provincial election was called and the government was defeated. The new government did not implement the Estates General's recommendations. Instead, it tabled a draft bill which proposed an MMP system with 77 riding seats and 24 to 27 party list seats. Electors would only cast one vote - party list seats would be awarded based on the parties' respective shares of the riding seat vote. ${ }^{92}$ The National Assembly struck a Select Committee to consider the draft bill which recommended that a new MMP electoral system be designed but expressed a number of caveats with the precise system set out in the draft bill and suggested that the government redraft the bill. ${ }^{93}$ In the end, the government did not proceed with the draft bill. ${ }^{94}$

\section{Ontario}

Following the example of British Columbia, the Ontario government decided in 2005 to also create a Citizens' Assembly to examine possible options for electoral reform..$^{95}$ The Legislative Assembly struck an all-party Select Committee on Electoral Reform to consider and report on options for electoral reform. In November 2005, the Select Committee recommended the Citizens' Assembly be given a broad mandate, that its proposals be put to the electorate at a referendum to be held at the same time as a provincial general election, and that the referendum be binding if approved by the majority of voters overall and the majority of voters in two-thirds of ridings. ${ }^{96}$

The Citizens' Assembly recommended that first-past-the-post be replaced by MMP. ${ }^{97}$ Under the Citizens' Assembly's proposed system, there would be a two-part ballot allowing votes for both a riding MPP and a preferred party. 90 riding seats would be elected under first-past-thepost while 39 party lists seats would be allocated based on the province-wide party vote. Candidates could run locally, on a party list, or both.
Unlike in New Zealand, there would be no provision for overhang seats if a party's share of riding seats exceeded its share of the vote and parties could only obtain party list seats if they achieved at least $3 \%$ of the party vote (i.e., there would be no riding seat threshold). ${ }^{98}$

The Citizens' Assembly's recommendations were put to the electorate in a referendum held at the same time as the 2007 provincial election. The Legislative Assembly had increased the threshold to make the result of the referendum binding to $60 \%$ of the overall vote and $50 \%$ of the vote in at least $60 \%$ of Ontario's ridings. ${ }^{99}$ Voters were asked "Which electoral system should Ontario use to elect members to the provincial legislature? The existing electoral system (firstpast-the-post) / the alternative electoral system proposed by the Citizens' Assembly (Mixed Member Proportional)?" ${ }^{100} 52 \%$ of voters voted in the referendum and $63 \%$ of those voting chose to retain the existing first-past-the-post system. ${ }^{101}$

\section{Can Parliament Unilaterally Reform Canada's Electoral System?}

The example of other Commonwealth democracies and Canada's provinces will provide the Special Committee on Electoral Reform a wide range of possible options for electoral reform. When and if an option for reform is chosen, the question that will be asked is whether Parliament can implement the change itself without first holding a referendum or seeking provincial consent to a constitutional amendment. Only the most drastic changes that go far beyond what is likely to be considered would require provincial consent - many changes can be made by ordinary legislation and even more can be made by a unilateral federal constitutional amendment under section 44 of the Constitution Act, 1982. Nor is there any requirement in Canadian law or convention to hold a referendum before changing the electoral system. 


\section{Only the most drastic electoral reforms require provincial consent}

Several provisions of Canada's Constitution set the framework for federal elections. Section 37 of the Constitution Act, 1867 requires the members of the House of Commons to "be elected" in varying numbers for the various provinces. ${ }^{102}$ Section 40 sets out the electoral districts into which the original provinces were divided "until the Parliament of Canada otherwise provides." 103 Section 41 provided that the pre-existing election laws of the several Provinces at the Union governed federal elections "until the Parliament of Canada otherwise provides."104 Section 51 requires "the number of members of the House of Commons and the representation of the provinces therein" to be readjusted after each decennial census. ${ }^{105}$ Section $51 \mathrm{~A}$ ensures that each province shall always have at least as many MPs as it does Senators. ${ }^{106}$ And section 52 allows Parliament to increase the number of MPs from time to time, "provided the proportionate Representation of the Provinces prescribed by this Act is not thereby disturbed." 107 Finally, section 3 of the Charter guarantees every citizen of Canada "the right to vote in an election of members of the House of Commons or of a legislative assembly and to be qualified for membership therein." 108

Under sections 40 and 41, Parliament has the power to change the boundaries of electoral districts, "the Proceedings at Elections" and the "Powers and Duties" of "Returning Officers" by ordinary legislation so long as in doing so it does not change the fact that MPs are elected, that every Canadian citizen can vote and run for election, and the number of ridings allocated to each province. A wide range of electoral reform could therefore be implemented by ordinary legislation. AV, STV, or MMP could all be implemented by ordinary legislation so long as the number of seats allocated to each province was not changed. Nothing in the Constitution mandates first-pastthe-post.

Changing the number of seats allocated to each province does require a constitutional amendment but it is the type of constitutional amendment that Parliament can and has made unilaterally on numerous occasions. From 1949 to 1982, section 91(1) of the Constitution Act, 1867 allowed Parliament to unilaterally amend "the Constitution of Canada" subject to certain enumerated exceptions. ${ }^{109}$ Since 1982, section 44 of the Constitution Act, 1982 allows Parliament to unilaterally amend "the Constitution of Canada in relation to the ... House of Commons." 110 Since 1949, Parliament has regularly amended the readjustment formula in section 51 and added seats for the territories under section 91(1) and section $44 .^{111}$

The Supreme Court has held that section 44, like section 91(1) before it, is limited to giving Parliament "the ability to unilaterally amend certain aspects of the Constitution that relate to [the federal] level of government, but which do not engage the interests of the other level of government." ${ }^{112}$ For example, changing the Senate from an appointed to an elected body (whether or not the elections had formal legal effect) or imposing fixed terms on Senators would alter the fundamental nature or role of the Senate in a way that engages provincial interests and thus precludes use of section $44 .^{113}$

None of the electoral reforms that are likely to be proposed would change the fundamental nature of the House of Commons in the way that changing the Senate from an appointed body where Senators served until death or retirement age to an elected body with term limits would have. None of the likely alternative electoral systems would change the House of Commons' fundamental role as an elected house elected on the basis of representation by population. Evidence of how much more fundamental the appointed nature of the Senate is to Canada's constitutional architecture than the particular electoral system used to elect MPs can be found in the legislative debates leading up to Confederation. Unlike the lengthy debates over whether the Senate should be elected or appointed, not a single mention was made of the electoral system that should be used to choose members of the House of Commons. ${ }^{114}$

An argument could be made that a constitutional amendment would be required to create multi-member districts or districts elected by party lists because section 40's reference to the four original provinces being "divided into Elec- 
toral Districts" precludes the adoption of proportional representation systems that break the current one-to-one relationship between MPs and their ridings. That argument is unlikely to succeed. All of section 40, not just the specific riding boundaries set out therein, applies only "until the Parliament of Canada otherwise provides." Even if that were not the case, implementing such a change would also be the kind of constitutional amendment Parliament can make on its own through section 44 .

The only changes that Parliament cannot unilaterally make to the federal electoral system are (1) those which would require amending section 3 of the Charter of Rights and Freedoms (i.e., depriving some citizens of the right to vote or run for election as an MP) which would require use of the general "seven provinces containing 50 percent of the electorate in aggregate" $(7 / 50)$ amending formula under section 38 of the Constitution Act, 1982 because it would amend the Charter and thus not just be a change "in relation to the ... House of Commons"; (2) making some seats in the House of Commons appointed rather than elected which would change the fundamental nature of the House of Commons as an elected body; (3) changing the principle of proportionate representation of the provinces in the House of Commons which expressly requires use of the general 7/50 amending formula under section 42(1)(a) of the Constitution Act, 1982 and in any event would be a change to the fundamental nature of the House of Commons; and (4) eliminating the right of a province to a number of MPs not less than the number of Senators it had in 1982, which expressly requires use of the unanimity formula under section 41 (b) of the Constitution Act, 1982. ${ }^{115}$

But it is very unlikely the federal government would consider making changes so drastic as to engage one of these exceptions. Whether the government ultimately decides to implement AV, MMP, STV, or some other variant of proportional representation, the essential characteristics of the House of Commons will remain the same - it will still be an entirely elected body with the representation of each province deter- mined by its respective share of Canada's population.

\section{There is no requirement to hold a referen- dum before reforming the electoral system}

The Official Opposition has repeatedly asked the government to commit to putting any proposed changes to a referendum before they are enacted. To date, the government has refused to do so; instead, it has promised that the Special Committee on Electoral Reform will consult widely with Canadians and has given it the power "to advise on additional methods for obtaining the views of Canadians," which could potentially include a referendum. The question of whether a referendum should be held before the electoral system is changed is purely a political one - neither law nor convention requires the government to hold a referendum before it makes changes to the current first-past-the-post system.

There is clearly no legal requirement to hold a referendum. Whether the changes are made by ordinary legislation or a constitutional amendment under section 44 of the Constitution Act, 1982, Parliament can enact the change itself. As provincial consent is not required, provincial legislation requiring a referendum to be held does not apply. ${ }^{116}$ The federal Referendum Act, enacted to allow for a referendum to be held outside Québec on the Charlottetown Accord, is permissive rather than mandatory - it allows the Governor in Council to direct the holding of a referendum "on any question relating to the Constitution of Canada" but does not require it to do so. ${ }^{117}$

Nor is there a constitutional convention requiring the government to hold a referendum before changing the electoral system. A constitutional convention is a rule of the constitution that is enforced by the political process, not the courts (although the courts do on occasion recognize whether a convention exists). Conventions must be distinguished from mere usage conventions are rules regarded as obligatory by the officials to which they apply whereas usages are just governmental practices which are ordinarily followed, but are not regarded as obligatory. ${ }^{118}$ 
Parliament has repeatedly passed constitutional amendments changing the proportionate representation of the various provinces in the House of Commons without first holding a referendum. The fact that some but not all provinces have chosen to put their electoral reform proposals to referenda does not mean that Parliament feels itself obliged to do so. To the contrary, Parliament has approved more far-reaching constitutional reforms (e.g. the patriation of the Constitution itself, the addition of further protections for aboriginal rights, the elimination of denominational school rights in certain provinces, and the Meech Lake Accord) without first seeking the views of the electorate. Its decision to hold a referendum once (vis-à-vis the Charlottetown Accord) does not evidence an intention to be bound to do so in the future.

There therefore is no constitutional convention requiring a referendum to be held before Parliament changes Canada's federal electoral system. Nor, for the reasons set out above, is there any need for provincial consent even if a constitutional amendment is required. The question of whether Canada should have a new electoral system and, if so, what form that system should take remains entirely in the hands of the MPs Canadians have already elected.

\section{Appendix A - Motion Establishing Special Committee on Electoral Reform}

That a Special Committee on electoral reform be appointed to identify and conduct a study of viable alternate voting systems to replace the first-past-the-post system, as well as to examine mandatory voting and online voting, and to assess the extent to which the options identified could advance the following principles for electoral reform:

1) Effectiveness and legitimacy: that the proposed measure would increase public confidence among Canadians that their democratic will, as expressed by their votes, will be fairly translated and that the proposed mea- sure reduces distortion and strengthens the link between voter intention and the election of representatives;

2) Engagement: that the proposed measure would encourage voting and participation in the democratic process, foster greater civility and collaboration in politics, enhance social cohesion and offer opportunities for inclusion of underrepresented groups in the political process;

3) Accessibility and inclusiveness: that the proposed measure would avoid undue complexity in the voting process, while respecting the other principles, and that it would support access by all eligible voters regardless of physical or social condition;

4) Integrity: that the proposed measure can be implemented while safeguarding public trust in the election process, by ensuring reliable and verifiable results obtained through an effective and objective process that is secure and preserves vote secrecy for individual Canadians;

5) Local representation: that the proposed measure would ensure accountability and recognize the value that Canadians attach to community, to Members of Parliament understanding local conditions and advancing local needs at the national level, and to having access to Members of Parliament to facilitate resolution of their concerns and participation in the democratic process;

that the Committee be directed to issue an invitation to each Member of Parliament to conduct a town hall in their respective constituencies and provide the Committee with a written report of the input from their constituents to be filed with the Clerk of the Committee no later than November 1, 2016 October 14, 2016;

that the Committee be directed to take into account the applicable constitutional, legal and implementation parameters in the development of its recommendations; accordingly, the Committee should seek out expert testimony on these matters; 
that the Committee be directed to consult broadly with relevant experts and organizations, take into consideration consultations that have been undertaken on the issue, examine relevant research studies and literature, and review models being used or developed in other jurisdictions;

that the Committee be directed to develop its consultation agenda, working methods, and recommendations on electoral reform with the goal of strengthening the inclusion of all Canadians in our diverse society, including women, Indigenous Peoples, youth, seniors, Canadians with disabilities, new Canadians, and residents of rural and remote communities;

that the Committee be directed to conduct a national engagement process that includes a comprehensive and inclusive consultation with Canadians, including through written submissions and online engagement tools;

that the Committee be directed to study and advise on additional methods for obtaining the views of Canadians;

that the Committee be composed of twelve (12) members of which five (5) shall be government members, three (3) shall be from the Official Opposition, two (2) shall be from the New Democratic Party, one (1) member shall be from the Bloc Québécois, and the Member for Saanich - Gulf Islands;

that changes in the membership of the Committee be effective immediately after notification by the Whip has been filed with the Clerk of the House;

that membership substitutions be permitted, if required, in the manner provided for in Standing Order 114(2);

that, with the exception of the Member for Saanich - Gulf Islands, all other members shall be named by their respective Whip by depositing with the Clerk of the House the list of their members to serve on the Committee no later than ten (10) sitting days following the adoption of this motion; that the Committee be chaired by a member of the government party; that, in addition to the Chair, there be one (1) Vice-Chair from the Official Opposition and one (1) Vice-Chair from the New Democratic Party, and that, notwithstanding Standing Order 106(3), all eandidates for the position of Chair or Vice-Chair from the Offl= eial Opposition all candidates for the position of Chair or Vice-Chair shall be elected by secret ballot, and that each candidate be permitted to address the Committee for not more than three (3) minutes;

that the quorum of the Committee be as provided for in Standing Order 118, provided that at least four (4) members are present and provided that one (1) member from the government party and one (1) member from an opposition party are present;

that the Committee be granted all of the powers of a standing committee, as provided in the Standing Orders, as well as the power to travel, accompanied by the necessary staff, inside and outside of Canada;

that the Committee have the power to authorize video and audio broadcasting of any or all of its proceedings; and

that the Committee present its final report no later than December 1, 2016.

\section{Appendix B - Initial Membership of the Special Committee on Electoral Reform}

Chair:

Francis Scarpaleggia (Lib.)

Vice-Chairs:

Scott Reid (Con.)

Nathan Cullen (NDP)

Members:

John Aldag (Lib.)

Alexandre Boulerice (NDP) 
Matt DeCourcey (Lib.)

Gérard Deltell (Con.)

Hon. Jason Kenney (Con.)

Elizabeth May (Green)

Sherry Romanado (Lib.)

Ruby Sahota (Lib.)

Luc Thériault (BQ)

\section{Endnotes}

* Josh Hunter, BA (Hons) (McMaster), LLB, MBA, MTS (Toronto), LLM (Cantab) is Counsel in the Constitutional Law Branch of the Ontario Ministry of the Attorney General. The opinions expressed in this opinion are solely those of the author and do not represent the views of the Attorney General of Ontario or the Province of Ontario.

1 Liberal Party of Canada, "Real Change: A Fair and Open Government" at 8, online: <www.liberal.ca/ files/2015/08/a-fair-and-open-government.pdf $>$.

2 Ibid.

3 Letter from the Right Honourable Justin Trudeau, "Minister of Democratic Institutions Mandate Letter", online: <www.pm.gc.ca/eng/ministerdemocratic-institutions-mandate-letter $>$.

4 House of Commons Notice Paper, 42nd Parl, 1st Sess, No 53 (11 May 2016) at VI.

5 Ibid at VII.

6 House of Commons Debates, 42nd Parl, 1st Sess, Vol 148, No 64 (2 June 2016) at 3919-50, 3963-80; House of Commons Debates, 42nd Parl, 1st Sess, Vol 148, No 67 (7 June 2016) at 4154-56. The full text of the amended motion is set out in Appendix A.

7 The initial membership of the Committee is set out in Appendix B.

8 House of Commons Debates, (2 June 2016) at 3927.

9 New Zealand Constitution Act, 1852 (UK), 15 \& 16 Vict, c 72, s 67; Constitution Act 1986 (NZ), 1986/114, s 10(4); Constitution Amendment Act 2005 (NZ), 2005/48, s 3.

10 New Zealand, Ministry for Culture and Heritage, "New Zealand History: The Road to MMP, Page 2 - First past the post" (2014), online: <www. nzhistory.net.nz/politics/fpp-to-mmp/firstpast-the-post>. Until 1881 and again from 1889 to 1903 , MPs were elected in a mix of singlemember and two- or three-member electorates.
New Zealand Constitution Act, 1852, supra note 9, ss 40-41; Electoral Districts Act 1858 (NZ), $1858 / 55$, s 2; Representation Act 1860 (NZ), 1860/12, s 4; Representation Act 1870 (NZ), 1870/15, s 3, Sch; Representation Act 1875 (NZ), s 4, Sch.; Representation Act 1881 (NZ), s 3, Sch.; Representation Act 1887 (NZ), 1887/7, s 3; Representation Amendment Act 1889 (NZ), 1989/6, s 2; Electoral Act 1902 (NZ), 1902/21, s 6; City Single Electorates Act 1903 (NZ), 1903/55, ss 2-3; Legislature Act 1908 (NZ), 1908/101, ss 17. From 1908 to 1913, a second-ballot system was used where, if no candidate won more than $50 \%$ of the votes in a riding, a run off would be held a week or two later between the top two candidates. 1908/226, ss 2-12; Legislature Amendment Act 1913 (NZ), 1913/36, s 4.

11 New Zealand Constitution Act, 1852, supra note 9, s 33; New Zealand Constitution Act, 1868 (No 1) (UK), 31 \& 32 Vict, c 57, ss 1-2; Legislative Council Act 1914 (NZ), 1914/59, ss 1, 4, 10-23, 33-36, 4042 , Sch 3.

12 Legislative Council Amendment Act 1915 (NZ), 1915/82, s 2; Legislative Council Amendment Act 1916 (NZ), 1916/17, ss 2-4; Legislative Council Amendment Act 1918 (NZ), 1918/15 ss 2-6; Legislative Council Abolition Act 1950 (NZ), 1950/3, s 2 .

13 Constitution Act 1986, supra note 9, s 10(4); Electoral Act 1993 (NZ), 1993/87.

14 New Zealand, Ministry for Culture and Heritage, "New Zealand History: The Road to MMP, Page 3 - The Royal Commission" (2014), online: <www.nzhistory.net.nz/politics/fpp-to-mmp/ royal-commission>; New Zealand, Royal Commission on the Electoral System, Towards a Better Democracy (1986, Wellington, Government Printer), online: <www.elections.org.nz/votingsystem/mmp-voting-system/report-royalcommission-electoral-system-1986>.

15 Electoral Referendum Act 1991 (NZ), 1991/152, s 3, Sch.

16 Electoral Referendum Act 1993 (NZ), 1993/101, s 2, Sch; New Zealand, Ministry for Culture and Heritage, "New Zealand History: The Road to MMP, Page 4 - Putting it to the vote" (2014), online: <www.nzhistory.net.nz/politics/fpp-tommp/putting-it-to-the-vote>; New Zealand, Ministry for Culture and Heritage, "New Zealand History: The Road to MMP, Page 5 - 1996 and beyond - the road to MMP" (2014), online: <www.nzhistory.net.nz/politics/fpp-to-mmp/ 1996-and-beyond $>$ [1996 and beyond].

17 Electoral Act 1993, supra note 13, s 150, Form 11. 
18 Ibid, ss 179, 185.

19 Ibid, s 127.

20 New Zealand, Electoral Commission, "SainteLaguë Allocation Formula" <www.elections.org. $\mathrm{nz} /$ voting-system/mmp-voting-system/saintelagu\%C3\%AB-allocation-formula>; Electoral Act 1993, supra note 13, ss 191-93.

211996 and beyond, supra note 16; New Zealand Electoral Commission, "Overall Results 2011 Referendum on the Voting System" (2011), online: <www.electionresults.govt.nz/ electionresults_2011/referendum.html>; Electoral Referendum Act 2010 (NZ), 2010/139, ss 4, 8, Schs 1-2.

22 Ibid, ss 74-78.

23 New Zealand, Electoral Commission, "Report of the Electoral Commission on the Review of the MMP Voting System" (2012), online: <www.elections. org.nz/sites/default/files/bulk-upload/documents/ Final_Report_2012_Review_of_MMP.pdf $>$.

24 Maori Representation Act 1867 (NZ), 1867/47, s 3; Electoral Act 1893 (NZ), 1893/18, ss 7, 149; Electoral Act 1902, supra note 10, ss 28, 168; Legislature Act 1908 (NZ), ss 37, 180

25 Electoral Act 1993, supra note 13, s 45.

26 New Zealand, Electoral Commission, "Māori Representation" (2014), online: <www.elections. org.nz/voting-system/maori-representation $>$.

27 Commonwealth of Australia Constitution Act (Cth), ss 7-24.

28 Ibid, ss 10, 31; Commonwealth Electoral Act 1902 (Cth).

29 Commonwealth of Australia Constitution Act, supra note 27, s 9.

30 Ibid, ss 31, 51(xxxvi).

31 Commonwealth Electoral Act 1902, supra note 28, ss $150-51$.

32 Australia, Australian Electoral Commission, "A Short History of Federal Election Reform in Australia" (2011), online: <www.aec.gov.au/ Elections/Australian_Electoral_History/history. htm>.

33 Commonwealth Electoral Act 1918 (Cth), s 124 [now s 240].

$34 \mathrm{Ibid}$, s 136(5)-(6) [now ss 274(7)-(10)]; Australia, Australian Electoral Commission, "Voting - House of Representatives" (2014), online: <www.aec.gov.au/Voting/How_to_Vote/Voting HOR.htm>; Australia, Australian Electoral Commission, "Counting the votes for the House of Representatives", online: <www.aec.gov.au/ Voting/counting/hor_count.htm $>$.

35 Commonwealth Electoral Act 1918, supra note 33, ss $123,135(5)-(10)$, as amended by Commonwealth
Electoral Act 1919 (Cth), ss 7, 9 and Commonwealth Electoral Act 1934 (Cth), s 8.

36 Ibid, s 128A [now s 245] as added by Commonwealth Electoral Act 1924 (Cth), s 1(3).

37 Ibid, ss 168, 211, 211A, 239; Australia, Australian Electoral Commission, "Voting - The Senate" (2016), online: <www.aec.gov.au/Voting/How_to_ Vote/Voting_Senate.htm $>$.

38 Commonwealth Electoral Act 1918, supra note 33 ss 135(5)-(7) [now ss 273(5)-(32)] as amended by Commonwealth Electoral Act 1948 (Cth), s 3; Australia, Australian Electoral Commission, "Counting the votes for the Senate", online: $<$ www. aec.gov.au/Voting/counting/senate_count.htm $>$.

39 Parliament of Australia, "Senate Composition", online: <www.aph.gov.au/ Senators_and_Members/Senators/Senate_ composition>.

40 Commonwealth Electoral Amendment Act 2016 (Cth); Eliza Borrello, "Senate reform: Electoral laws passed after marathon Parliament sitting", Australian Broadcasting Corporation (18 March 2016), online: <www.abc.net.au/news/2016-03-18/ senate-electoral-reform-laws-passed/7258212>; "Senate passes voting law changes after marathon sitting", Sydney Morning Herald (18 March 2016), online: <www.smh.com.au/federal-politics/ political-news/senate-passes-voting-law-changesafter-marathon-sitting-20160318-gnlvo3.html>.

41 Australia, Australian Electoral Commission, "Voting - The Senate", online: <www.aec.gov. au/Voting/How_to_vote/Voting_Senate.htm>; Australia, Australian Electoral Commission, "Voting is different this federal election", online: <www.aec.gov.au/Voting/How_to_vote/files/ senate-how-to-vote-2016.pdf>.

42 Day $v$ Australian Electoral Officer for the State of South Australia, [2016] HCA 20; Madden $v$ Australian Electoral Officer for the State of Tasmania, [2016] HCA 20.

43 Commonwealth Electoral Amendment Act 2016, supra note 40 s $42 \mathrm{~A}$.

44 Constitution Act 1902 (NSW), ss 29, Sch 7; Electoral Act 2002 (Vic), ss 93, 113-14; Electoral Act 2002 (Qld), ss 122,128; Electoral Act 1985 (SA), ss 76(2), 96; Electoral Act 1907 (WA), ss 128(3), 144(2)-(3a); Electoral Act 2011 (NT), ss 50, 126-29.

45 Electoral Act 2004 (Tas), ss 102(1), 144-45, Sch 4; Electoral Act 1992 (ACT), ss 132, 182-185, Sch 4.

46 Constitution Act 1902, supra note 44, s 22A, Sch 6; Electoral Act 2002, supra note 42 ss 93A, 114A; Electoral Act 1985, supra note 42 ss 76(1), 95; Electoral Act 1907, supra note 42 ss 128(2), 146(2), Sch 1. 
47 Electoral Act 2004 (Tas), ss 102(2), 144-45, Sch 5.

48 Constitution Act Amendment Act 1922 (Qld), s 2.

49 Constitution Act 1902, supra note 44, s 7A7B; Proportional Representation (Hare-Clark) Entrenchment Act 1994 (ACT), ss 4-5.

50 Representation of the People Act 1983 (UK), 1983, c 2, ss 18, 23(1), Sch 1. For most of England's history, multi-member constituencies with widely varying franchises were the norm until the passage of the Reform Acts in the nineteenth century. Representation of the People Act 1832 (UK), 2 \& 3 Will IV, c 45; Representation of the People Act, 1867 (UK), 30 \& 31 Vict, c 102; Representation of the People Act 1884 (UK), 48 \& 49 Vict, c 3; Redistribution of Seats Act 1885 (UK), 48 \& 49 Vict, c 23.

51 Richard Cavendish, Royal Commission on Systems of Election (London: King's Printer, 1910) at 9, 3637.

52 Representation of the People Bill, 1917-1918 sess, cl 15.

53 UK, HC, Parliamentary Debates, 5th ser, vol 95, cols 1133-1255 (21 November 1917); UK, HC Parliamentary Debates, 5th ser, vol 95, cols 11331255 (4 July 1917); UK, HC, Parliamentary Debates, 5th ser, vol 99, cols 1302-26 (21 November 1917); UK, HC, Parliamentary Debates, 5th ser, vol 99, cols 1406-69 (22 November 1917).

54 UK, HL, Parliamentary Debates, 5th ser, vol 27, cols 824-904 (21 January 1918); UK, HL, Parliamentary Debates, 5th ser, vol 27, cols 905-74 (22 January 1918).

55 UK, HC, Parliamentary Debates, 5th ser, vol 101, cols 1601-1705 (30 January 1918); UK, HC, Parliamentary Debates, 5th ser, vol 101, cols 17781823, (31 January 1918).

56 UK, HL, Parliamentary Debates, 5th ser, vol 28, cols 321-55 (4 February 1918); UK, HC, Parliamentary Debates, 5th ser, vol 101, cols 2170-89 (5 February 1918); UK, HL, Parliamentary Debates, 5th ser, vol 28, cols 399-432 (6 February 1918); UK, HC, Parliamentary Debates, 5th ser, vol 101, cols 224091 (6 February 1918); Representation of the People Act 1918 (UK), 8 Geo V, c 64, s 20(2).

57 UK, HC, Parliamentary Debates, 5th ser, vol 106, cols 63-117 (13 May 1918).

58 Proportional Representation Bill, 1921 sess; UK, HC Parliamentary Debates, 5th ser, vol 140 cols 613-93 (5 April 1921); Parliamentary Elections (Alternative Vote) Bill, 1923 sess [HL]; UK, HL, Parliamentary Debates, 5th ser, vol 53, cols 413-39 (20 March 1923); Representation of the People Act 1918, (UK) Amendment Bill 1924 (HC); UK, HC,
Parliamentary Debates, 5th ser, vol 170, cols 859944 (29 February 1924).

59 Representation of the People (No 2) Bill, 1931 sess; UK, HC, Parliamentary Debates, 5th ser, vol 252, cols 1013-1134 (12 May 1931); UK, HC, Parliamentary Debates, 5th ser, vol 81, cols 565611 (2 July 1931); UK, HC, Parliamentary Debates, 5th ser, vol 255, cols 1940-41 (27 July 1931).

60 Parliamentary Voting System and Constituencies Act 2011 (UK), c 1, s 1.

61 Ibid., ss 8-9, Sch 10, 12 Part 1.

62 United Kingdom, The Electoral Commission, Referendum on the voting system for UK Parliamentary elections: Report on the May 2011 referendum (London: October 2011) at 16-17, online: <www.electoralcommission.org.uk/ data/assets/pdf_file/0019/141328/Final-PVSreport.pdf $>$.

63 House of Lords Act 1999 (UK), c 34, ss 1-2; Standing Orders of the House of Lords Relating to Public Business, 2013 (HL 105), ss 9-11; House of Lords, "By-elections in the House of Lords", online: <www.parliament.uk/mps-lords-andoffices/offices/lords/house-of-lords-informationoffice/by-elections/>.

64 Northern Ireland Act 1998 (UK), c 47, s 34.

65 Government of Wales Act 2006 (UK), c 32, ss 6-9; Scotland Act 1998 (UK), c 46, ss 5-8.

66 In Northern Ireland, “Doyou support the agreement reached at the multi-party talks on Northern Ireland and set out in Command Paper 3883?" Northern Ireland (Entry into Negotiations, etc.) Act 1996 (UK), c 11, s 4; Northern Ireland Negotiations (Referendum) Order 1998, SI 1998/1126, ss 3, Sch 1. In Scotland, "I agree / do not agree that there should be a Scottish Parliament" and "I agree / do not agree that a Scottish Parliament should have tax-varying powers." Referendums (Scotland and Wales) Act 1997 (UK), c 61, s 1, Sch 1. In Wales, "I agree / do not agree that there should be a Welsh Assembly." Ibid, s 2, Sch 2.

67 British Columbia, Legislative Assembly, Hansard, 37th Parl, 4th Sess, No 12 (30 April 2003) at 6355-74; British Columbia, Citizens' Assembly on Electoral Reform Terms of Reference and Duties of the Chair, online: <citizensassembly.arts.ubc. ca/resources/terms_of_reference.pdf $>$; BC OIC 0495-2003; BC OIC 0496-2003.

68 British Columbia, Citizens' Assembly on Electoral Reform, Making Every Vote Count: The Case for Electoral Reform in British Columbia - Final Report (December 2004) at 13, online: <citizensassembly. arts.ubc.ca/resources/final_report.pdf $>$. 
69 British Columbia, Citizens' Assembly on Electoral Reform, Making Every Vote Count: The Case for Electoral Reform in British Columbia - Technical Report (December 2004) at 17-20, online: <citizensassembly.arts.ubc.ca/resources/ TechReport(full).pdf $>$.

70 Electoral Reform Referendum Act, SBC 2004, c 47; Electoral Reform Referendum Regulation, BC Reg 47/2005, s 7, Sch.

71 Elections BC, Statement of Votes: Referendum on Electoral Reform (17 May 2005) at 9, online: $<$ www.elections.bc.ca/docs/SOV-Refcomplete_r. pdf $>$.

72 Electoral Reform Referendum 2009 Act, SBC 2008, c 9; Electoral Reform Referendum 2009 Act Regulation, BC Reg 266/2008, s 23, Sch.

73 Elections BC, Statement of Votes: Referendum on Electoral Reform (12 May 2009) at 17, online: $<$ www.elections.bc.ca/docs/rpt/2009Ref/2009Ref-SOV.pdf>.

74 New Brunswick, Commission on Legislative Democracy, Final Report and Recommendations (31 December 2004) at 31-47, online: <www. electionsnb.ca/content/dam/enb/pdf/cld/ CLDFinalReport-e.pdf $>$.

75 Ibid at 47-49.

76 New Brunswick, Improving the Way Government Works: Government Response to the Final Report of the Commission on Legislative Democracy at 5-6, online: <leg-horizon.gnb.ca/e-repository/ monographs/30000000044072/30000000044072. pdf $>$.

77 New Brunswick, An Accountable and Responsible Government: A New Generation of Canadian Leadership ... Renewing Democracy in New Brunswick: The Government's Response to the Final Report of the CommissiononLegislative Democracyat 10-13, online: <leg-horizon.gnb.ca/e-repository/ monographs/30000000044730/30000000044730. pdf $>$.

78 Prince Edward Island, Commissioner on Electoral Reform, Report (18 December 2003) at 103, online: $<$ www.gov.pe.ca/photos/original/er_premier2003. pdf $>$.

79 Prince Edward Island, General Assembly, Hansard, 66th Gen Ass, 2nd Sess (16 December 2004) at 1093-1115.

80 Prince Edward Island, Commission on PEI's Electoral Future, Final Report (28 October 2005) at 16-19, online: <www.gov.pe.ca/photos/original/ elec_elecrfrm05.pdf>.

81 Proportional System Regulations, PEI Reg EC567/05, ss 2-3, Sch.
82 Prince Edward Island, White Paper on Democratic Renewal (July 2015) at 9, online: <www.gov.pe.ca/ photos/original/democraticrenew.pdf $>$.

83 Ibid. at 14-16.

84 Prince Edward Island, Special Committee on Democratic Renewal, First Report of the First Session Sixty-Fifth General Assembly: Recommendations in Response to the White Paper on Democratic Renewal (27 November 2015) at 2-3, 22, online: <www.assembly.pe.ca/sittings/2015fall/ reports/23_1_2015-27-11-report.pdf>.

85 Prince Edward Island, General Assembly ${ }_{2}$ Hansard, 65th Gen Ass, 1st Sess (27 November 2015) at 1842-54.

86 Prince Edward Island, Special Committee on Democratic Renewal, First Report of the Second Session Sixty-Fifth General Assembly: Recommendations in Response to the White Paper on Democratic Renewal - A Plebiscite Question (15 April 2016) at 19-20, online: <www.assembly. pe.ca/sittings/2016spring/reports/23_1_2016-1504-report.pdf>.

87 Prince Edward Island, General Assembly, Hansard, 65th Gen Ass, 2nd Sess (15 April 2016) at 369-73; Prince Edward Island, General Assembly, Hansard, 65th Gen Ass, 2nd Sess (13 May 2016) at 1348-54.

88 An Act to Amend the Plebiscites Act, SPEI 2016, c 19.

89 Michael Tutton, "Nova Scotia premier floats ranked ballots after weak voter turnout," The Globe and Mail (15 July 2015), online: <www. theglobeandmail.com/news/politics/nova-scotiapremier-floats-ranked-ballots-after-weak-voterturnout/article25525120/>.

90 Steve Lambert, "Manitoba's planned electoral reform could lead to lower voting age," Winnipeg Free Press (25 December 2015), online: <www. winnipegfreepress.com/local/manitobas-plannedelectoral-reform-could-lead-to-lower-votingage-363526091.html>.

91 Québec, Organizing Committee of the Estates General on the Reform of Democratic Institutions, Take your rightful place! (Québec: Gouvernement de Québec, 2003) at 13-15, 34-36, online: <www.institutions-democratiques.gouv.qc.ca/ publications/rapport_comite_directeur_en.pdf $>$.

92 Draft Bill, Election Act, 1st Sess, 37th Leg, Québec, 2004, cls 288, 443, 446-53; Québec, Draft Legislation Replacing the Election Act Background Paper (2004) at 10, 14, online: <www.institutionsdemocratiques.gouv.qc.ca/publications/resume_ avant_projet_loi_en.pdf $>$. 
93 Québec, Select Committee on the Election Act, Report (31 May 2006) at 16-30.

94 Québec, Sécretariat à l'accès à l'information et à la réforme des institutions démocratiques, "Activitiés legislatives: Avant-projet de loi remplaçant la Loi électorale," online : <www.institutionsdemocratiques.gouv.qc.ca/institutionsdemocratiques/activites-legislatives.htm $>$.

95 Election Amendment Act, SO 2005, c 23, s 3; Citizen's Assembly on Electoral Reform, O Reg $82 / 06$.

96 Ontario, Select Committee on Electoral Reform, 38th Parl, 2nd Sess, Report on Electoral Reform (30 November 2005) at 6-7.

97 Ontario, Citizens' Assembly on Electoral Reform, One Ballot, Two Votes: A New Way to Vote in Ontario: Recommendation of the Ontario Citizens' Assembly on Electoral Reform (Ontario, Queen's Printer, 2007) at 2-3, online: <www.citizensassembly.gov. on.ca/assets/One\%20Ballot,\%20Two\%20Votes. pdf $>$.

98 Ontario, Citizens' Assembly on Electoral Reform, Democracy at work: The Ontario Citizens' Assembly on Electoral Reform: A record of Ontario's first citizens' assembly process (Ontario, Queen's Printer, 2007) at 144-56, online: <www.citizensassembly. gov.on.ca/assets/Democracy\%20at\%20Work\%20 - \%20 The \%20 Ontario \% 20 Citizens \% 27\%20 Assembly\%20on\%20Electoral\%20Reform.pdf >.

99 Electoral System Referendum Act, SO 2007, c 1, ss 2, 4-5.

100 Ibid, s 3; Ontario, OIC 1398/2007.

101 Elections Ontario, Statistical Results, online: $<$ www.elections.on.ca/content/dam/NGW/ sitecontent/2014/historical-results/2007/ Referendum/Statistical\%20Results.pdf $>$.

102 Constitution Act, 1867 (UK), 30 \& 31 Vict, c 3, s 37. The number of MPs allocated to each province are determined by the application of section 51 of the Constitution Act, 1867 and the Electoral
Boundaries Readjustment Act, RSC 1985, c E-3. The Constitution Act, 1871 allowed Parliament to give newly created provinces representation in Parliament and confirmed the validity of it already having done so for Manitoba. Constitution Act, 1871 (UK), 34 \& 35 Vict, c 28, ss 2, 5; Manitoba Act, SC 1870, c 3, s 4; Alberta Act, SC 1905, c 3, s 5; Saskatchewan Act, SC 1905, c 42, s 5.

103 Constitution Act, 1867, supra note 102, s 40. Electoral districts are now established by the Electoral Boundaries Readjustment Act, supra note 102 and the proclamations issued from time to time thereunder.

104 Constitution Act, 1867, supra note 102, s 41. Parliament has done this by passing the Canada Elections Act, SC 2000, c 9 and the Parliament of Canada Act, RSC 1985, c P-1.

105 Constitution Act, 1867, supra note 102, s 51.

106 Ibid, s 51A.

107 Ibid, s 52. The readjustment formula has been regularly amended. Statute Law Revision Act, 1893 (UK), 56 \& 57 Vict, c 14; British North America Act, 1943 (UK), 6 \& 7 Geo VI, c 30; British North America Act, 1946 (UK), 9 \& 10 Geo VI, c 63; British North America Act, SC 1952, c 15; Constitution Act, 1974, SC 1974-75-76, c 13; Constitution Act (No 1), SC 1974-75-76, c 28; Constitution Act (Representation), SC 1986, c 8, Part I; Constitution Act, (Nunavut), SC 1998, c 15, Part 2; Fair Representation Act, SC 2011, c 26, s 2.

108 Canadian Charter of Rights and Freedoms, s 3, Part I of the Constitution Act, 1982, being Schedule B to the Canada Act 1982 (UK), 1982, c 11.

109 Constitution Act, 1867, supra note 102 at s 91(1) as enacted by the British North America (No 2) Act, 1949 (UK), 13 Geo VI, c 81.

110 Constitution Act, 1982, s 44, being Schedule B to the Canada Act 1982 (UK), 1982, c 11.

111 Elections Ontario, supra note 101.

112 Reference re Senate Reform, 2014 SCC 32 at paras 45-48, [2014] 1 SCR 704 [Senate Reference]. For the similar restrictions that applied under the former s 91(1), see Upper House Reference, [1980] 1 SCR 54 at 77-78.

113 Senate Reference, supra note 112. at paras 54-80.

114 Province of Canada, Parliamentary Debates on the Subject of Confederation of the British North American Provinces (Quebec: Hunter, Rose \& Co, 1865).

115 Constitution Act, 1982, supra note 110 at ss 38, 41(b), 42(1)(a), 44.

116 Constitutional Amendment Approval Act, RSBC 1996, c 67; Constitutional Referendum Act, RSA 2000, c C-25. 
117 Referendum Act, SC 1992, c 30, s 3(1).

118 Peter W Hogg, Constitution of Canada, 5th ed (Toronto: Carswell, 2007), looseleaf at para 1.10. 